\title{
Biological Mother
}

National Cancer Institute

\section{Source}

National Cancer Institute. Biological Mother. NCI Thesaurus. Code C96580.

A female who contributes to the genetic makeup of her offspring from the fertilization of her ovum. 